\title{
The firm lifecycle as a determiant of going private decisions
}

\author{
Robert Gutsche - University of St. Gallen, Switzerland \\ Lucia Schroeter - University of Dubai, UAE \\ E-Mail : Lschroeter@ud.ac.ae
}

\begin{abstract}
We examine the impact of corporate lifecycle on the likelihood of becoming a voluntary going private firm. We apply the firm's capital mix as a measure for the stage in a firm's lifecycle. In doing so, we provide a framework and evidence on firm characteristics of going private firms. We find that the decision to go private depends on the firm's lifecycle. Young firms, with low retained earnings are more likely to go private than mature or old firms. We also find that relative firm characteristics of going private and non-going private firms are consistent with the findings on relative firm characteristics in $\mathrm{M} \& \mathrm{~A}$ activity research for acquirers (bidders, non-targets) vs. nonacquirer (non-bidders, and targets) and that these relative firm characteristics of going private and non-going private firms stay constant throughout all stages of the corporate lifecycle.
\end{abstract}

Keywords : going private, public to private, voluntary delistings, corporate lifecycle

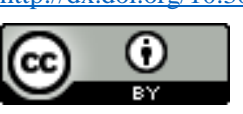

2523-6547 - Copyright: (C) 2017 The Authors. This is an open access article distributed under the terms of the Creative Commons Attribution License, which permits unrestricted use, distribution, and reproduction in any medium, provided the original author and source are credited.
Selection and Peer-review under the responsibility of the UNIVERSITY OF DUBAI - DUBAI BUSINESS SCHOOL
- ICABML Conference Committee. 


\section{Introduction}

A going-private transaction is a deal where a privately held entity buys out the shareholders of a public firm and delists it from the stock exchange (Boubaker, Cellier, \& Rouatbi, 2014; Gaughan, 2011). Hence, this transaction can be considered as an acquisition of a firm (or a part of a firm) through private equity or/and debt investors. Therefore, a going private firm is a target firm. A huge amount of studies (Bae, Chang, \& Kim, 2013; Belkaoui, 1978; K. Palepu, 1982; Powell, 2004; Sorensen, 2000; Stevens, 1973; Tsagkanos, 2008; Weir, Laing, \& Wright, n.d.; Wi Saeng Kim \& Lyn, 1991) show that target firms are different from acquiring firms, target firms or nontarget firms, and that acquirers, target, and non-targets have particular differing firm characteristics (Gutsche, 2013). Moreover, similar differences between going-private and non-going private firms have been identified in the literature that analyzes the relative firm characteristics of going private firms (shortly before the going private transaction) and a non-going private control group (Boot, Gopalan, \& Thakor, 2008; Gleason, Payne, \& Wiggenhorn, 2007; Halpern, Kieschnick, \& Rotenberg, 1999; Kieschnick, 1998; Lehn \& Poulsen, 1989; Loh, 1992; Maupin, 1987).

A recent finding in M\&A activity research additionally suggests that the firm's lifecycle is an important determinant of M\&A activity (Owen \& Yawson, 2010). Firms in their early stage grow rather internally (organic growth) than externally (by mergers and acquisitions) (Stubbart \& Knight, 2006) and internal growth firms are attractive takeover targets (Carow, Heron, \& Saxton, 2004). Mature firms have sometimes difficulties to grow internally and consider external growth opportunities (Christensen \& Montgomery, 1981; Rumelt, 1982; Stimpert \& Duhaime, 1997). However, the opportunities for external growth depend largely on their financial resources: Younger firms are often smaller and have only limited financial resources. In contrast, mature firms are mostly larger than firms in an early stage of their lifecycle, which makes it difficult for others to acquire them (G. Bhabra, 2008; Gaver \& Gaver, 1993). As a consequence, a connection between lifecycle and M\&A activity is often suggested (Owen \& Yawson, 2010; Ritter \& Welch, 2002; Rydqvist \& Högholm, 1995).

The going private firm when acquired by a private investor has remarkable similarities to an M\&A target firm (here the acquirer/bidder is typically a publicly held firm). However, it is still an open empirical question whether this relationship between firm lifecycle and M\&A activity also exists for a going private transaction. Therefore, in this paper, we apply the organizational theories lifecycle approach for M\&A activity (Adizes, 1979; Greiner, 1997; Miller \& Friesen, 1984) and the findings from related research (the above mentioned finding in M\&A activity studies) to voluntary going private transactions. We hypothesize that going private firms have characteristics, which are very similar to target firms, and that the going private transaction depends on the firms' lifecycle. Going private firms are younger and they have more growth opportunities than non-going private firms. Therefore, we examine (1) the impact of corporate lifecycle on the likelihood of becoming a voluntary going private firm. Further, we examine (2) if there is an indication of the stage the firm has reached in its lifecycle when it voluntarily decides for a going private step.

The stage in a firm's lifecycle can be determined by the firm's capital mix (retained earnings to total equity or total assets). In corporate lifecycle studies the capital mix served as a good indicator for firm lifecycle (DeAngelo, DeAngelo, \& Stulz, 2006; Owen \& Yawson, 2010). Main proposition of these studies is the significant positive relation between firm lifecycle and M\&A activity. This also is in line with the general findings on M\&A activity: Undistributed profits allow firms to make larger investments (like the acquisition of another firm). Therefore we adapted the capital mix lifecycle approach in this study.

\section{Framework}

M\&A research suggests that M\&A activity is driven by the target firm's performance, its financial resources and its growth potential, the potential agency conflicts within the target firm, and the target firm's market value (Bae et al., 2013; Belkaoui, 1978; K. Palepu, 1982; Powell, 2004; Sorensen, 2000; Stevens, 1973; Tsagkanos, 2008; Weir et al., n.d.; Wi Saeng Kim \& Lyn, 1991).

The inefficient management hypothesis suggests that M\&A activity is a control mechanism to discipline selfinterested managers (Fama \& Miller, 1972; K. G. Palepu, 1986). This implies that target firms are less profitable than non-target firms and may imply for going private firms a negative relationship between going private firms and non-going private firms (Maupin, 1984, 1987).

The growth resource mismatch hypothesis addresses the growth potential and the resources available to realize internal or external growth and suggests that high growth firms with low financial resources are attractive takeover 
targets, and that low growth (or mature) firms with high financial resources are more likely the acquiring firms (Harris \& Stewart, 1982; K. G. Palepu, 1986; Powell, 2004; Shim \& Okamuro, 2011). Hence, the financial resources and growth might be relevant for determining going private firms and non-going private firms (Evans, Poa, \& Rath, 2005; Kieschnick, 1998; Lehn \& Poulsen, 1989).

Smaller firms might lack the available resources to acquire larger firms. Hence, smaller firms will have a much higher likelihood of becoming a target firm. This so called size hypothesis may apply also for going private firms (Ambrose \& Megginson, 1992; J. W. Bartley \& Boardman, 1986; Dietrich \& California, 1984; Hasbrouck, 1985; K. G. Palepu, 1986; Singh, 1975; Trahan \& Shawky, 1992). We, therefore, expect going private firms to be smaller than non-going private firms.

Agency problems may result from managers maximizing their own benefits more than the benefits of the company. Agency problems are indicated by an increased level of free cash flow. Free cash flow as defined by Jensen is the "cash flow in excess of that required to fund all of a firm's projects that have positive net present values when discounted at the relevant cost of capital" (Jensen, 1986, 1987, 1988). Hence, takeovers are external control mechanisms that alleviate agency problems (Company, Jensen, \& Meckling, 1976; Jensen \& Ruback, 1983). However, even though several studies identified the free cash flow as an important determinant, the free cash flow as described by Jensen can hardly be identified due to a lack of information. Nevertheless, most studies suggest a positive relationship with regard free cash flow (from published financial statements) between target and non-target firms (G. S. Bhabra, 2008; Davis \& Stout, 1992; Sorensen, 2000). A similar relationship for going private and non-going private firms is suggested. Therefore, we hypothesize that the proportion of free cash flow will have a positive impact on the going private decision.

According to research on going private determinants and M\&A activity in general, the most important factors in distinguish going private firms from non-going private firms are profitability, financial resources, growth, and importantly size. ${ }^{1}$

The valuation hypothesis describes that target firms are often undervalued (J. Bartley \& Boardman, 1990; Hasbrouck, 1985; Marris, 1964; K. G. Palepu, 1986; K. Palepu, 1982; Tobin, 1969) or the acquirer overvalued when paying with shares (Bi \& Gregory, 2011; Shleifer \& Vishny, 2003). We presume that going private does not occur very frequently when the firm is overvalued.

With regard to M\&A activity, for going private firms also corporate governance variables have been of interested. So far, research identified various factors, which might be used to measure the level of corporate governance of a firm. Owen \& Yawson (2010) measure corporate governance e.g. with a governance index, which proxies for the level of shareholder rights and at the same time is an aggregate of 24 governance provisions. They further use an entrenchment index, which aggregates six governance provisions. They also construct a dummy variable to distinguish between classified board or not. Following their findings, we expect firms with low level of corporate governance to decide to leave the public capital market.

Corporate lifecycle studies show that firms develop over time and that the firms organizational structure evolves and the firm's strategy changes from each stage in corporate life (Greiner, 1997; Miller \& Friesen, 1984). M\&A activity provides evidence that the corporate lifecycle determines acquisition activity (Owen \& Yawson, 2010). However, only few studies investigate corporate lifecycle and the going private decision. Some studies examine firm characteristics over the whole quotation life and provide new insights how some factors might accelerate the going private decision (Bharath \& Dittmar, 2010; Mehran \& Peristiani, 2010). However, the stage of corporate life at which listed firms voluntarily go private is still not explored. Hence, the approach in this study is to examine corporate lifecycle as a determinant of going private transactions. The stage in a corporate lifecycle can be approximated by the capital mix which is the proportion of retained earnings to total equity and retained earnings to total assets (DeAngelo et al., 2006; Grabowski \& Mueller, 1975; Owen \& Yawson, 2010). According to these studies, we distinguish between old, mature and young stage of corporate lifecycle: We divide all examined firms into groups with the highest $25 \%$ of RE/TE respectively RE/TA, with the lowest $25 \%$ of RE/TE (TA) and those firms in-between with midsize amount of RE/TE (TA). Firms with high RE/TE (TA) are considered to be old, firms with midsize amount to be mature and those with the lowest amount of RE/TE (TA) as young. We expect firms with low amount of RE/TE (TA) to have a higher probability of becoming a voluntary going private firm.

1 The going private (again similar to the M\&A) research is often amended by studies that analyze the ability of gaining abnormal returns through going private transactions (Billett, Jiang, \& Lie, 2010; DeAngelo, DeAngelo, \& Rice, 1984; Denis, 1992; Lehn \& Poulsen, 1989; Renneboog, Simons, \& Wright, 2007). 


\section{Methodology and statement of hypothesis}

According to the findings in the M\&A activity and going private literature, we hypothesize that the going private activity is determined by the stage of the lifecycle of a firm (measured as the proportion of retained earnings to total equity RE/TE or to total assets RE/TA) as well as other firm characteristics that typically drive M\&A activity. In our analysis we, therefore, test for the stage of the lifecycle (by RE/TE and RE/TA), for profitability (roa, measured as return on assets), Free Cash Flow ( $f f f)$, financial resources (leverage, measured as the level of leverage), the firm's market value valuation ( $p e$ and $p b$ : price-earnings ratio and price-to-book ratio), firm size (marketcap in terms of the firms' market capitalization), analysts' coverage (analyst), the firms' capital expenditure (capex), and other factors that refer to the firms' corporate governance (CFO SOX certification ( $c f o$ sox), auditors' opinion (auditor), level of accruals (accruals). 
Table 1 summarizes our expectations as follows:

Table 1:Summary of hypotheses

\begin{tabular}{|c|c|c|}
\hline Lifecycle stage & $\begin{array}{l}\text { Stage in the firms' lifecycle measured as retained earnings to total assets or } \\
\text { total equity. We expect young firms with low accumulated retained earnings to } \\
\text { decide to go private. }\end{array}$ & - \\
\hline roa & The lower return on assets, the higher the probability of a going private. & - \\
\hline fcff & $\begin{array}{l}\text { The higher free cash flow to the firm, the higher the going private probability } \\
\text { according to Jensen (1986). Kieschnick's (1998) findings are contrary. }\end{array}$ & $+/-$ \\
\hline marketcap & The smaller the market capitalization, the higher the going private probability. & - \\
\hline analyst & The lower the analyst coverage, the higher the going private probability. & - \\
\hline auditor & If no Big 4 auditor at the IPO, the more likely a going private. & - \\
\hline leverage & The higher the leverage, the higher the going private probability. & + \\
\hline pe and $\mathrm{pb}$ & $\begin{array}{l}\text { The lower price-to-earnings and price-to-book ratios, the higher the going } \\
\text { private probability. }\end{array}$ & - \\
\hline corp gov & $\begin{array}{l}\text { The lower the level of corporate governance, the higher the going private } \\
\text { probability. }\end{array}$ & - \\
\hline
\end{tabular}

We construct logit models with the aim to test (1) for the impact of corporate lifecycle on the going private probability, (2) for the impact of lifecycle stages on going private decision and (3) for the test of robustness including corporate governance variables into our sample. We set all going private firms one and all non-going private firms zero. Our basic model $^{2}$ has the formula:

$$
\begin{aligned}
& \operatorname{Ln}\left[p_{i} /\left(1-p_{i}\right)\right]=\alpha_{0}+\alpha_{1} R E / \overline{T A}(T E)_{i}+\alpha_{2} \text { marketcap }_{i}+\alpha_{3} \text { analyst }_{i}+ \\
& \alpha_{4} \text { auditor }_{i}+\alpha_{5} \text { fcff }_{i}+\alpha_{6} \text { tlta }_{i}+\alpha_{7} \text { roa }_{i}+\alpha_{8} \overline{p e}_{i}+\alpha_{9} \overline{p b}_{i}+\alpha_{10} \text { capex }_{i}+\alpha_{11} \text { corpgov }_{i}+\varepsilon_{i}
\end{aligned}
$$

We additionally control for the impact on years, since the environment of the firm could have been impacted by a particular year (e.g. changing accounting requirements during the years and new standards of SOX).

\section{Results}

The following chapter presents the results of our empirical analysis. First, we present the descriptive statistics results. Second, we describe the results of our first logit model focusing on the influence of corporate lifecycle on the going private decision. Third, we show the results of the logit model investigating the role of lifecycle stage. Last, we test for robustness including corporate governance variables into our sample.

\section{Data set and sample firms}

Our sample consists of 1'501 IPOs, which went public between 1985 and 2013 on the three U.S. major exchanges NYSE, AMEX and Nasdaq. We use the Thomson SDC New Issues database in order to obtain all IPOs during this period. We exclude penny stock IPOs, ADRs, REITs as well as firms from the financial sector according to previous literature. The number of analyzed IPOs is further reduced by the data availability in Datastream,

\footnotetext{
${ }^{2}$ The model construction is inspired by Gutsche (2013).
} 
Compustat and CRSP database. We divide our sample into voluntary going private firms and staying public firms (non-going private). We use delisting codes from CRSP database in order to find out which companies went private voluntary. We assume all delistings with the codes 570 and 573 as positive. Firms, which stay public, are nongoing private firms (control group) with code 100. We identify 201 voluntary going private firms and 1'300 staying public (or non-going private) firms. For all firms we collect data from their last public fiscal year and include them into our analysis. Table 1 contains descriptive statistics (mean, median and standard deviation) of going privates and non-going privates firms with regard to market capitalization (marketcap), retained earnings $(R E)$, total assets $(T A)$ and total equity $(T E)$. 
Table 2:Descriptive statistics

Going private firms

Staying public (Non-going private firms)

\begin{tabular}{|c|c|c|c|c|c|c|}
\hline & \multicolumn{3}{|c|}{$\mathrm{N}=201$} & \multicolumn{3}{|c|}{$\mathrm{N}=1{ }^{\prime} 300$} \\
\hline & mean & median & $\begin{array}{l}\text { standard } \\
\text { deviation }\end{array}$ & mean & median & $\begin{array}{l}\text { standard } \\
\text { deviation }\end{array}$ \\
\hline marketcap & 3.423 & 3.141 & 1.850 & 5.831 & 5.926 & 1.777 \\
\hline total assets & 473.261 & 63.596 & $1^{\prime} 639.452$ & 3'540.777 & 568.364 & $27^{\prime} 692.530$ \\
\hline total equity & 118.324 & 18.456 & 438.390 & $1^{\prime} 062.111$ & 251.693 & 3'698.692 \\
\hline $\begin{array}{l}\text { retained } \\
\text { earnings }\end{array}$ & -96.236 & -16.001 & 434.403 & 61.751 & 0 & 3'942.103 \\
\hline
\end{tabular}

Impact of lifecycle on the likelihood of becoming a going private

Our first empirical model is a binomial logit model evaluating the impact of firm's lifecycle on the likelihood of becoming a voluntary going private firm. The dependent variable is set to one if the firm became private during the observation period and zero if it is part of the control group. Table 2 presents the results of the impact of RE/TE and RE/TA as proxies for a firm's lifecycle on the likelihood of becoming a going private. The table includes results for both measures of the lifecycle whilst controlling for years. The results reported in both models show a significant negative relationship between the firm's lifecycle and the likelihood of becoming a voluntary going private. This finding supports our hypothesis that lifecycle of a firm is a relevant factor influencing the timing of the going private decision. These findings imply that firms with lower amounts of RE/TE (or RE/TA) are more likely to leave voluntarily the public capital market in order to become private again. In model (1), firm size measured as market capitalization (marketcap), analyst coverage (analyst), auditor at IPO (auditor), return on assets (roa), free cash flow to the firm ( fcff), total leverage to total assets (leverage) as well as price-to-book ratio $(p b)$ and capital expenditures (capex) are all also significantly related to the possibility of becoming a going private. Leverage, price-to-book ratio and capex are positively related to the probability. All other factors influence the probability negatively. These findings are consistent with those from previous studies (e.g. Mehran \& Peristiani, 2010) and suggest that small firms with low analyst coverage, no Big 4 auditor at their IPO and low returns are more likely to go private. The findings do not support the agency theory of Jensen (1986), who expects large free cash flows to be one of the reasons for a voluntary delisting. On contrary, our results show that firms with low free cash flow might rather go private, which confirms the finding of e.g. Kieschnick (1998).

Further, our findings suggest firms with more leverage, higher price-to-book ratio and higher capital expenditures are more likely to go private. However, our findings of leverage are consistent with those of Gleason, Payne, \& Wiggenhorn (2007). We expect undervalued firms to have a higher probability to go private. Our findings suggest the contrary, as the price-to-book ratio influence the going private step positively.

Our findings in model (2) are similar to those of model (1). RE/TA as a proxy for firm's lifecycle has a negative significant impact on the likelihood of becoming a going private firm. The less accumulated retained earnings a firm has, the higher is the probability that it will go private. 
Table 3:Logit regressions for the going private probability

\begin{tabular}{|c|c|c|c|c|}
\hline Variables & (1) & t-stat & (2) & t-stat \\
\hline$R E / T E$ & \multicolumn{2}{|c|}{$-0.009 * *-1.81$} & & \\
\hline \multicolumn{3}{|l|}{$R E / T A$} & $-2.464 * * *$ & -4.85 \\
\hline marketcap & $-0.617 * * *$ & -6.20 & $-0.710 * * *$ & -5.77 \\
\hline analyst & \multicolumn{2}{|c|}{$-0.747 * *-1.90$} & -0.138 & -0.29 \\
\hline auditor & $-1.264 * * *$ & -3.26 & -0.655 & -1.21 \\
\hline roa & $-0.810 * * *$ & -2.90 & $0.928 *$ & 1.70 \\
\hline$f c f f$ & \multicolumn{2}{|c|}{$-0.847 * *-1.89$} & 0.638 & 0.68 \\
\hline tlta & $0.691 * * *$ & 2.71 & -0.735 & -1.41 \\
\hline pe & 0.001 & 1.34 & $0.002 * *$ & 2.22 \\
\hline$p b$ & $0.004 * * *$ & 3.99 & 0.001 & 0.28 \\
\hline capex & $0.027 * * *$ & 3.42 & $0.034 * * *$ & 3.25 \\
\hline constant & $7.657 * * *$ & 5.90 & $8.847 * * *$ & 6.88 \\
\hline Observations & 1241 & & 1255 & \\
\hline Wald & $154.02 * * *$ & & $145.49 * * *$ & \\
\hline $\mathrm{R}^{2}$ & $67.43 \%$ & & $76.90 \%$ & \\
\hline \multicolumn{5}{|c|}{$\begin{array}{l}\text { The table reports the relationship between firm's lifecycle and the going private step. The sample includes 1'501 } \\
\text { IPOs going public between } 1985 \text { and } 2013 \text { on NASDAQ, NYSE or AMEX. The independent variable is set to } \\
\text { one if the company went private and zero if it is part of the control group. RE/TE and RE/TA is the ratio of } \\
\text { retained earnings to total equity and total assets, respectively. marketcap is the logarithm of market capitalization } \\
\text { calculated as number of shares outstanding multiplied by the share price, analyst is a binary variable set to one } \\
\text { if the market capitalization of the company is above the median of the whole sample, auditor is a binary variable }\end{array}$} \\
\hline
\end{tabular}


set to one when the IPO is audited by a Big 4 auditor, roa is the return on assets measured as net income over total assets, $f c f f$ is the free cash flow to the firm measured as free cash flow to the firm over total assets, pe is the price-to-earnings ratio, $p b$ is the price-to-book ratio, tlta is the amount of leverage calculated as total leverage over total assets, capex are the capital expenditures calculated over total assets. We also control for years, which is not included in the table. $* * * * * / *$ indicates statistical significance at the $1 \% / 5 \% / 10 \%$ level.

In this model, the influence of return on assets has a reverse effect on the going private likelihood as in model (1). A possible explanation for this contrasting finding might be due to the correlation between RE/TA and return on assets in model (2). Both models explain a large part of the voluntary going private decision. While model (1) has a $\mathrm{R}^{2}$ of more than $67 \%$, model (2) explains almost $77 \%$.

\section{Lifecycle stage and the likelihood of becoming a going private}

Findings from the first regression models showed that lifecycle plays a significant role in determining the probability of a voluntary going private step. However, these two models did not answer the question about the lifecycle stage in which a company might decide for such a step. We, therefore, apply the modified model of Miller \& Friesen (1984), which Owen \& Yawson (2010) also use in their study and distinguish between young, mature and old companies according to the amount of their accumulated retained earnings divided by total assets. We divide our sample into these three subsamples, in which firms with the $25 \%$ lowest retained earnings to total assets belong to the young ones, those with $25 \%$ highest retained earnings to total assets to the old ones and all companies in-between have the classification mature. Table 3 presents the findings of the lifecycle stage analysis. The probability of becoming a voluntary going private firm is significantly higher in firms with low retained earnings to total assets. This finding is consistent with our expectation that firms with lower amount of retained earnings to total assets correspond in this characteristic with typical target companies. We also find significant evidence that the higher the amount of retained earnings to total assets, the less likely a company will decide for a voluntary step into privacy. Both mature and old companies show negative relationship to the going private probability. Other tested variables show mostly significant influence on the going private probability. The smaller a company is, the higher the probability of a voluntary delisting. This finding is consistent with e.g. Mehran \& Peristiani (2010). In contrasst to Jensen's free cash flow hypothesis (1986), we expected low free cash flow to the firm to influence the going private probability (Kieschnick, 1989, 1998). Our findings are consistent with those of Kieschnick (1989, 1998) and are statistically significant at 5\% level. We find no statistical significance for analyst coverage. However, if the auditor at the IPO was not one of the Big 4, but only a minor player, the higher the probability that a firm decides for a voluntary going private. We further expect companies with lower profit, measured as return on assets, to be more likely to go private. Our findings are significant and consistent with our expectation. They are in line with the findings of M\&A activity literature.

We find weak evidence for the impact of leverage. The more debt a firm has, the more likely it might decide for privacy. Surprisingly, there is reverse effect of valuation factors. Both, the price-to-earnings ratio and the price-tobook ratio show significant positive influence on the going private probability. However, their impact measured by the coefficient is extremely low. The impact of capital expenditures is also low, which might be due to the fact that typical going private firms are similar to typical target firms and their expenses are rather high, which confirms our expectations. Furthermore, we also control for years and find significant evidence. 
Table 4:Logit regression models for different lifecycle stages

\begin{tabular}{|c|c|c|c|c|c|c|}
\hline Variables & (1) & t-stat & $(2)$ & t-stat & (3) & t-stat \\
\hline young & $2.510 * * *$ & 6.55 & & & & \\
\hline mature & & & $-1.478 * * *$ & -3.75 & & \\
\hline old & & & & & $-1.950 * * *$ & -2.62 \\
\hline marketcap & $-0.643 * * *$ & -5.79 & $-0.622 * * *$ & -6.25 & $-0.649 * * *$ & -6.09 \\
\hline analyst & -0.490 & -1.18 & -0.617 & -1.51 & -0.543 & -1.43 \\
\hline auditor & $-1.144 * * *$ & -2.74 & $-1.239 * * *$ & -3.26 & $-1.288 * * *$ & -3.19 \\
\hline roa & $-0.652 * *-2$ & & $-0.687 * *-2$ & & $-0.744 * * *$ & -2.76 \\
\hline$f_{c f f}$ & $-0.878 * *-2$ & & $-0.904 * *-1$ & & $-1.075 * * *$ & -3.08 \\
\hline tlta & 0.296 & 1.06 & $0.487 * * 1$. & & $0.612 * * 2.03$ & \\
\hline pe & $0.002 * * *$ & 3.08 & $0.002 * * 1$. & & $0.002 *$ & 1.73 \\
\hline$p b$ & $0.004 * * 2$ & & $0.005 * * *$ & 2.60 & $0.004 * * *$ & 3.38 \\
\hline capex & $0.031 * * *$ & 3.64 & $0.030 * * *$ & 3.53 & $0.022 * * *$ & 3.09 \\
\hline constant & $6.505 * * *$ & 5.83 & $8.045^{* * *}$ & 6.45 & $8.434 * * *$ & 6.88 \\
\hline Observations & 1255 & & 1255 & & 1255 & \\
\hline Wald & $160.75 * * *$ & & $163.40 * * *$ & & $144.89 * * *$ & \\
\hline $\mathrm{R}^{2}$ & $73.03 \%$ & & $69.26 \%$ & & $69.02 \%$ & \\
\hline \multicolumn{7}{|c|}{$\begin{array}{l}\text { The table reports lifecycle stage and the probability of a going private step. The sample includes } 1 \text { '501 IPOs going public between } 1985 \text { and } 2013 \text { on NASDAQ, NYSE or } \\
\text { AMEX. The independent variable is set to one if the company went private and zero if it is part of the control group. Young, mature and old are dummy variables set to one if } \\
\text { the firms RE/TA lie in the lower } 25 \% \text {, in the middle } 50 \% \text { or in the higher } 25 \% \text {, respectively. RE/TA is the ratio of retained earnings to total assets. marketcap is the logarithm of } \\
\text { market capitalization calculated as number of shares outstanding multiplied by the share price, analyst is a binary variable set to one if the market capitalization of the company } \\
\text { is above the median of the whole sample, auditor is a binary variable set to one when the IPO is audited by a Big } 4 \text { auditor, roa is the return on assets measured as net income } \\
\text { over total assets, fcff is the free cash flow to the firm measured as free cash flow to the firm over total assets, pe is the price-to-earnings ratio, pb is the price-to-book ratio, tlta is } \\
\text { the amount of leverage calculated as total leverage over total assets, capex are the capital expenditures calculated over total assets. We also control for years, which is not included } \\
\text { in the table. } * * * * * * * \text { indicates statistical significance at the } 1 \% / 5 \% / 10 \% \text { level. }\end{array}$} \\
\hline
\end{tabular}




\section{Robustness control for the effect of corporate governance}

Following Bell, Moore, \& Filatotchev (2012) and Krishnan et al. (2011), who both examined the post IPO performance and its dependence on corporate governance variables, we expect that the level of corporate governance has also an influence on the going private decision of a firm. Corporate governance plays a relevant role for various stakeholders, especially investors. Investors on the public capital market often avoid companies with bad corporate governance. We therefore expect firms with low level of corporate governance to be more likely to decide voluntarily to leave the public capital market and become private. Hence, we evaluate the robustness of our results including corporate governance variables into our model. The first corporate governance variable we control for is CFO Sarbanes-Oxley Act certification (cfo sox). We expect firms with no SOX certification from their CFO, confirming their financial statement is in line with the requirements of SEC to be more likely to go private due to their low level of corporate governance. We also include auditor's opinion into our corporate governance variables. External auditor gives a firm an unqualified opinion if its financial statements are in accordance with the requirements. We expect firms with no unqualified opinion from their auditor to be more likely to go private. Further, we include accruals as a corporate governance measure into our model as we expect firms with high accruals might be managing their earnings and therefore hurt corporate governance standards.

The results reported in table 4 indicate that firm's lifecycle has still a significant negative relationship to the probability of a voluntary going private also when including corporate governance factors. RE/TE and RE/TA are both still significant determinants of going private probability. The lower the retained earnings to total assets or to total equity respectively are, the higher is the probability of a firm to leave the public capital market. These finding confirms the results from the previous regressions.

Corporate governance variables influence the going private probability. We found significant evidence for CFO SOX certification (cfo sox) as well as for the level of accruals (accruals). No evidence is found for the influence of auditor's opinion (auditor) on the going private probability. Surprisingly, our results suggest that CFO SOX certification ( $f$ fo sox) has a positive significant influence on the likelihood of the voluntary step into privacy. This finding is contrary to our expectations. A possible explanation for this finding might be the point in time in which we analyzed firms. In order to be able to distinguish between going private and non-going private firms we conducted a logit regression at the time shortly before the announcement of this step. This means, that we collected our data from the last public fiscal year of going private firms. Because these firms decide to leave the market voluntarily, it might be their aim to present transparent and true information in their financial statements as many financial markets participants make their observations.

We further find a significant negative relationship between the amount of accruals (accruals) and the voluntary going private decision. This means that the lower the amount of accruals is, the higher is the probability to leave the public capital market. This finding was not expected. A possible explanation for our finding might be in the role and interpretation of accruals. According to Louis \& Robinson (2005) is the interpretation of accruals unclear. We expected high level of accruals to be an indication for managed earnings. Firms, which manage their earnings, would therefore have a low level of corporate governance, which would increase the going private probability. 
Table 5:Logit regressions for lifecycle controlling for corporate governance

\begin{tabular}{|c|c|c|c|c|c|c|}
\hline Variables & $\begin{array}{l}\text { cfo sox } \\
\text { Coefficient } \\
\text { (t-stat) }\end{array}$ & $\begin{array}{l}\text { opinion } \\
\text { Coefficient } \\
\text { (t-stat) }\end{array}$ & $\begin{array}{l}\text { accruals } \\
\text { Coefficient } \\
\text { (t-stat) }\end{array}$ & $\begin{array}{l}\text { cfo sox } \\
\text { Coefficient } \\
\text { (t-stat) }\end{array}$ & $\begin{array}{l}\text { opinion } \\
\text { Coefficient } \\
\text { (t-stat) }\end{array}$ & $\begin{array}{l}\text { accruals } \\
\text { Coefficient } \\
\text { (t-stat) }\end{array}$ \\
\hline$R E / T E$ & $\begin{array}{l}-0.008 * * \\
(-2.07)\end{array}$ & $\begin{array}{l}-0.008^{*} \\
(-1.78)\end{array}$ & $\begin{array}{l}-0.009^{*} \\
(-1.77)\end{array}$ & & & \\
\hline$R E / T A$ & & & & $\begin{array}{l}-2.501 * * * \\
(-4.37)\end{array}$ & $\begin{array}{l}-2.504 * * * \\
(-4.78)\end{array}$ & $\begin{array}{l}-2.442 * * * \\
(-4.73)\end{array}$ \\
\hline marketcap & $\begin{array}{l}-0.623 * * * \\
(-6.04)\end{array}$ & $\begin{array}{l}-0.616^{* * * *} \\
(-6.26)\end{array}$ & $\begin{array}{l}-0.609 * * * \\
(-6.11)\end{array}$ & $\begin{array}{l}-0.721 * * * \\
(-5.73)\end{array}$ & $\begin{array}{l}-0.709 * * * \\
(-5.78)\end{array}$ & $\begin{array}{l}-0.696^{* * * *} \\
(-5.63)\end{array}$ \\
\hline analyst & $\begin{array}{l}-1.632 * * * \\
(-3.62)\end{array}$ & $\begin{array}{l}-0.717 * \\
(-1.81)\end{array}$ & $\begin{array}{l}-0.838 * * \\
(-2.07)\end{array}$ & $\begin{array}{l}-1.031 * * \\
(-1.98)\end{array}$ & $\begin{array}{l}-0.148 \\
(-0.32)\end{array}$ & $\begin{array}{l}-0.240 \\
(-0.49)\end{array}$ \\
\hline auditor & $\begin{array}{l}-1.536 * * * \\
(-3.67)\end{array}$ & $\begin{array}{l}-1.266^{* * *} \\
(-3.28)\end{array}$ & $\begin{array}{l}-1.293 * * * \\
(-3.32)\end{array}$ & $\begin{array}{l}-0.984 * \\
(-1.76)\end{array}$ & $\begin{array}{l}-0.627 \\
(-1.16)\end{array}$ & $\begin{array}{l}-0.710 \\
(-1.32)\end{array}$ \\
\hline roa & $\begin{array}{l}-0.720 * * \\
(-2.31)\end{array}$ & $\begin{array}{l}-0.786^{* * *} \\
(-2.83)\end{array}$ & $\begin{array}{l}-0.807 * * * \\
(-2.86)\end{array}$ & $\begin{array}{l}0.952 * * \\
(2.06)\end{array}$ & $\begin{array}{l}0.818 \\
(1.54)\end{array}$ & $\begin{array}{l}0.876 \\
(1.62)\end{array}$ \\
\hline$f c f f$ & $\begin{array}{l}-0.677 \\
(-1.38)\end{array}$ & $\begin{array}{l}-0.779 * \\
(-1.73)\end{array}$ & $\begin{array}{l}-0.882 * * \\
(-1.98)\end{array}$ & $\begin{array}{l}0.858 \\
(0.86)\end{array}$ & $\begin{array}{l}0.504 \\
(0.59)\end{array}$ & $\begin{array}{l}0.620 \\
(0.66)\end{array}$ \\
\hline tlta & $\begin{array}{l}0.482^{*} \\
(1.84)\end{array}$ & $\begin{array}{l}0.647 * * \\
(2.50)\end{array}$ & $\begin{array}{l}0.687 * * * \\
(2.65)\end{array}$ & $\begin{array}{l}-1.273 * * \\
(-2.09)\end{array}$ & $\begin{array}{l}-0.764 \\
(-1.45)\end{array}$ & $\begin{array}{l}-0.769 \\
(-1.44)\end{array}$ \\
\hline pe & $\begin{array}{l}0.002 \\
(1.54)\end{array}$ & $\begin{array}{l}0.001 \\
(1.21)\end{array}$ & $\begin{array}{l}0.001 \\
(1.09)\end{array}$ & $\begin{array}{l}0.002 * * \\
(2.27)\end{array}$ & $\begin{array}{l}0.002 * * \\
(2.46)\end{array}$ & $\begin{array}{l}0.002 * * \\
(2.09)\end{array}$ \\
\hline$p b$ & $\begin{array}{l}0.003 * * * \\
(3.64)\end{array}$ & $\begin{array}{l}0.004 * * * \\
(4.00)\end{array}$ & $\begin{array}{l}0.004 * * * \\
(3.90)\end{array}$ & $\begin{array}{l}-0.001 \\
(-0.43)\end{array}$ & $\begin{array}{l}0.001 \\
(0.27)\end{array}$ & $\begin{array}{l}0.001 \\
(0.29)\end{array}$ \\
\hline capex & $\begin{array}{l}0.020 * * * \\
(2.76)\end{array}$ & $\begin{array}{l}0.026^{* * * *} \\
(3.44)\end{array}$ & $\begin{array}{l}0.026^{* * * *} \\
(3.29)\end{array}$ & $\begin{array}{l}0.025^{* *} \\
(2.36)\end{array}$ & $\begin{array}{l}0.032 * * * \\
(3.05)\end{array}$ & $\begin{array}{l}0.032 * * * \\
(3.09)\end{array}$ \\
\hline corp gov & $\begin{array}{l}2.390 * * * \\
(4.34)\end{array}$ & $\begin{array}{l}0.318 \\
(0.89)\end{array}$ & $\begin{array}{l}-0.109 * * * \\
(-3.33)\end{array}$ & $\begin{array}{l}2.400 * * * \\
(3.39)\end{array}$ & $\begin{array}{l}-0.475 \\
(-0.82)\end{array}$ & $\begin{array}{l}-0.010 * * \\
(-2.54)\end{array}$ \\
\hline constant & $\begin{array}{l}8.195 * * * \\
(5.23)\end{array}$ & $\begin{array}{l}7.614 * * * \\
(5.87)\end{array}$ & $\begin{array}{l}7.625^{* * *} \\
(5.97)\end{array}$ & $\begin{array}{l}9.389 * * * \\
(5.89)\end{array}$ & $\begin{array}{l}8.997 * * * \\
(7.37)\end{array}$ & $\begin{array}{l}8.800 * * * \\
(6.91)\end{array}$ \\
\hline Obs. & 1241 & 1241 & 1237 & 1255 & 1255 & 1251 \\
\hline Wald & $138.35 * * *$ & $155.12 * * *$ & $160.53 * * *$ & $148.67 * * *$ & $146.96 * * *$ & $150.56^{* * *}$ \\
\hline $\mathrm{R}^{2}$ & $71.36 \%$ & $67.51 \%$ & $67.24 \%$ & $79.61 \%$ & $76.99 \%$ & $76.74 \%$ \\
\hline
\end{tabular}

2523-6547 - Copyright: @ 2017 The Authors. This is an open access article distributed under the terms of the Creative Commons Attribution License, which permits unrestricted use, distribution, and reproduction in any medium, provided the original author and source are credited. 
The table reports the relationship between firm's lifecycle and the going private step controlling for corporate governance. The sample includes 1'501 IPOs going public between 1985 and 2013 on NASDAQ, NYSE or AMEX. The independent variable is set to one if the company went private and zero if it is part of the control group. RE/TE and RE/TA is the ratio of retained earnings to total equity and total assets, respectively. marketcap is the logarithm of market capitalization calculated as number of shares outstanding multiplied by the share price, analyst is a binary variable set to one if the market capitalization of the company is above the median of the whole sample, auditor is a binary variable set to one when the IPO is audited by a Big 4 auditor, roa is the return on assets measured as net income over total assets, $f c f f$ is the free cash flow to the firm measured as free cash flow to the firm over total assets, $p e$ is the price-to-earnings ratio, $p b$ is the price-to-book ratio, tlta is the amount of leverage calculated as total leverage over total assets, capex are the capital expenditures calculated over total assets. corp gov refers to cfo sox, opinion or accruals. cfo sox is a binary variable set to one if the certification document fully complies with SEC requirements and is signed by the CFO, opinion is a binary variable set to one if the auditor opinion is non-qualified, accruals is the accruals ratio measured as aggregate accruals based on net operating assets. We also control for years, which is not included in the table. ***/**/* indicates statistical significance at the $1 \% / 5 \% / 10 \%$ level. 
Louis \& Robinson (2005) argue that the role of accruals is vague. According to them, accruals might be interpreted as managers' opportunism but also as their optimism. In addition, our analysis contains accruals of firms from their last fiscal year before their announcement of a going private. Again, it might be the case that firms pursue clear and transparent financial statements so shortly before their ownership change. They might therefore lower their level of accruals in order to increase their level of corporate governance.

Our test for corporate governance not only focuses on CFO SOX certification (cfo sox) and the level of accruals (accruals), but also on auditor's opinion (opinion). In both tested models, presented in table 4, we only found weak evidence for the influence of auditor's opinion on the going private probability. We further find higher significance for analyst coverage (analyst). The fewer analysts cover a firm, the higher is the probability that this firm decides voluntary to leave the public capital market. All other tested variables are consistent with findings from the previous models.

\section{Robustness control for corporate governance during lifecycle stages}

Table 5 presents results from three logit regression models in which we control for CFO SOX certification ( $c f o$ sox) with the aim to find out which stage of the corporate lifecycle is the one with the highest probability for a step into privacy. Our findings suggest that firms with low retained earnings to total assets (RE/TA), which corresponds to young firms, are those with the highest probability for a voluntary step into privacy. Mature and old firms with higher accumulated retained earnings, respectively, are less likely to decide for a going private. Our finding is consistent with our previous models presented in table 3. Including CFO SOX certification (cfo sox) into our sample, we obtained similar results also for further tested variables. In addition, we find negative significant influence for analyst coverage (analyst). Our finding suggests that firms covered by fewer analysts are more likely to decide to leave the public capital market voluntarily. This finding is consistent for all three models presented in table 5. For young firms, we still could not find any evidence for the influence of leverage. We expected firms with higher amount of debt to total assets to be more likely to go private. Our finding suggest this positive relationship but with no empirical evidence.

According to our results, young firms (young) measured by the amount of their retained earnings to total assets as a proxy for their lifecycle stage with small size measured as market capitalization (marketcap), low analyst coverage (analyst), no Big 4 auditor at their IPO (auditor), with low return on assets (roa), low free cash flow $(f c f f)$, with high valuation ( $p e, p b)$, high capital expenditures (capex) and a certification from their CFO about the accordance of their financial statements to SOX ( $c f o$ sox) are those with the highest probability of a voluntary delisting. We consider our control variables findings as robust as their not only confirm our previous analysis, but are also in line with previous findings of other researchers of the M\&A activity studies and studies on going private transactions (e.g. Kieschnick, 1989, 1998). As there is no previous study about the lifecycle stage of going privates firms, we could compare our results to; we refer to the study of Owen \& Yawson (2010), who examined lifecycle stages and M\&A transactions. According to them, a typical bidder firm is one, measured by retained earnings to total assets, which in its last lifecycle stage and therefore old. This confirms also our findings, because a typical going private firm correlate in its characteristics with a typical target firm, as showed in the theoretical part of our paper above. Hence, we can assume the reverse, when a typical bidder is old measured by retained earnings to total assets, then a typical target is young. As going private firms are alike to target firms, our findings are also consistent with those of Owen \& Yawson (2010).

Table 6 presents results from three logit regression models in which we control for the amount of accruals (accruals) with the aim to find out which stage of the corporate lifecycle is the one with the highest probability for a step into privacy. Our findings confirm the results from the previous models presented in table 5, in which we are controlling for CFO SOX certification ( $c f o$ sox). Again, firms in the early corporate lifecycle stage named young firms (young) are those, which decide for a voluntary step into privacy with the highest probability compared to non-going private firms. 
Table 6:Logit regressions controlling for corporate governance during lifecycle stages I/II

\begin{tabular}{|c|c|c|c|c|c|c|}
\hline Variables & $(1)$ & t-stat & (2) & t-stat & (3) & t-stat \\
\hline young & $2.456^{* * *}$ & 6.09 & & & & \\
\hline mature & & & $-1.153 * * *$ & -2.98 & & \\
\hline old & & & & \multicolumn{3}{|c|}{$-2.737 * *-2.54$} \\
\hline marketcap & $-0.667 * *$ & -6.02 & $-0.636 * * *$ & -6.07 & $-0.694 * * *$ & -5.76 \\
\hline analyst & $-1.311 * *$ & -2.85 & $-1.472 * * *$ & -3.22 & $-1.546 * * *$ & -3.62 \\
\hline auditor & $-1.302 * *$ & -3.19 & $-1.411 * * *$ & -3.44 & $-1.743 * * *$ & -3.79 \\
\hline roa & \multicolumn{2}{|c|}{$-0.570 *-1.79$} & \multicolumn{2}{|c|}{$-0.634 *-1.88$} & \multicolumn{2}{|c|}{$-0.642 * *-2.29$} \\
\hline$f c f f$ & \multicolumn{2}{|c|}{$-0.794 *-1.78$} & -0.766 & -1.52 & \multicolumn{2}{|c|}{$-0.920 * *-2.31$} \\
\hline tlta & 0.047 & 0.20 & 0.277 & 1.12 & 0.344 & 0.99 \\
\hline pe & $0.003 * * *$ & 2.84 & \multicolumn{2}{|c|}{$0.002 * * 1.98$} & \multicolumn{2}{|c|}{$0.002 * * 1.96$} \\
\hline$p b$ & \multicolumn{2}{|c|}{$0.003 * 2.47$} & \multicolumn{2}{|c|}{$0.004 * * 2.17$} & \multicolumn{2}{|c|}{$0.004 * 2.47$} \\
\hline capex & $0.025 * * *$ & 3.13 & $0.023 * * *$ & 2.83 & \multicolumn{2}{|c|}{$0.015 * * 2.20$} \\
\hline cfo sox & $2.283 * * *$ & 3.89 & $2.230 * * *$ & 4.03 & $2.785 * * *$ & 4.51 \\
\hline constant & $6.848 * * *$ & 4.62 & $8.514 * * *$ & 5.38 & $9.193 * * *$ & 6.16 \\
\hline Observations & \multicolumn{2}{|l|}{1255} & \multicolumn{2}{|l|}{1255} & \multicolumn{2}{|l|}{1255} \\
\hline Wald & \multicolumn{2}{|c|}{$136.88 * * *$} & \multicolumn{2}{|l|}{$143.66 * * *$} & \multicolumn{2}{|l|}{$113.77 * * *$} \\
\hline $\mathrm{R}^{2}$ & \multicolumn{2}{|c|}{$76.11 \%$} & \multicolumn{2}{|l|}{$72.43 \%$} & \multicolumn{2}{|l|}{$73.77 \%$} \\
\hline
\end{tabular}

The table reports lifecycle stage and the probability of a going private step controlling for corporate governance. The sample includes 1 '501 IPOs going public between 1985 and 2013 on NASDAQ, NYSE or AMEX. The independent variable is set to one if the company went private and zero if it is part of the control group. Young, mature and old are dummy variables set to one if the firms RE/TA lie in the lower $25 \%$, in the middle $50 \%$ or in the higher $25 \%$, respectively. RE/TA is the ratio of retained earnings to total assets. marketcap is the logarithm of market capitalization calculated as number of shares outstanding multiplied by the share price, analyst is a binary variable set to one if the market capitalization of the company is above the median of the whole sample, auditor is a binary variable set to one when the IPO is audited by a Big 4 auditor, roa is the return on assets measured as net income over total assets, $f c f f$ is the free cash flow to the firm measured as free cash flow to the firm over total assets, pe is the price-to-earnings ratio, $p b$ is the price-to-book ratio, tlta is the amount of leverage calculated as total leverage over total assets, capex are the capital expenditures calculated over total assets, $c f o$ sox is a binary variable set to one if the certification document fully complies with SEC requirements and is signed by the CFO. We also control for years, which is not included in the table. $* * * / * * / *$ indicates statistical significance at the $1 \% / 5 \% / 10 \%$ level. 
Table 7:Logit regressions controlling for corporate governance during lifecycle stages II/II

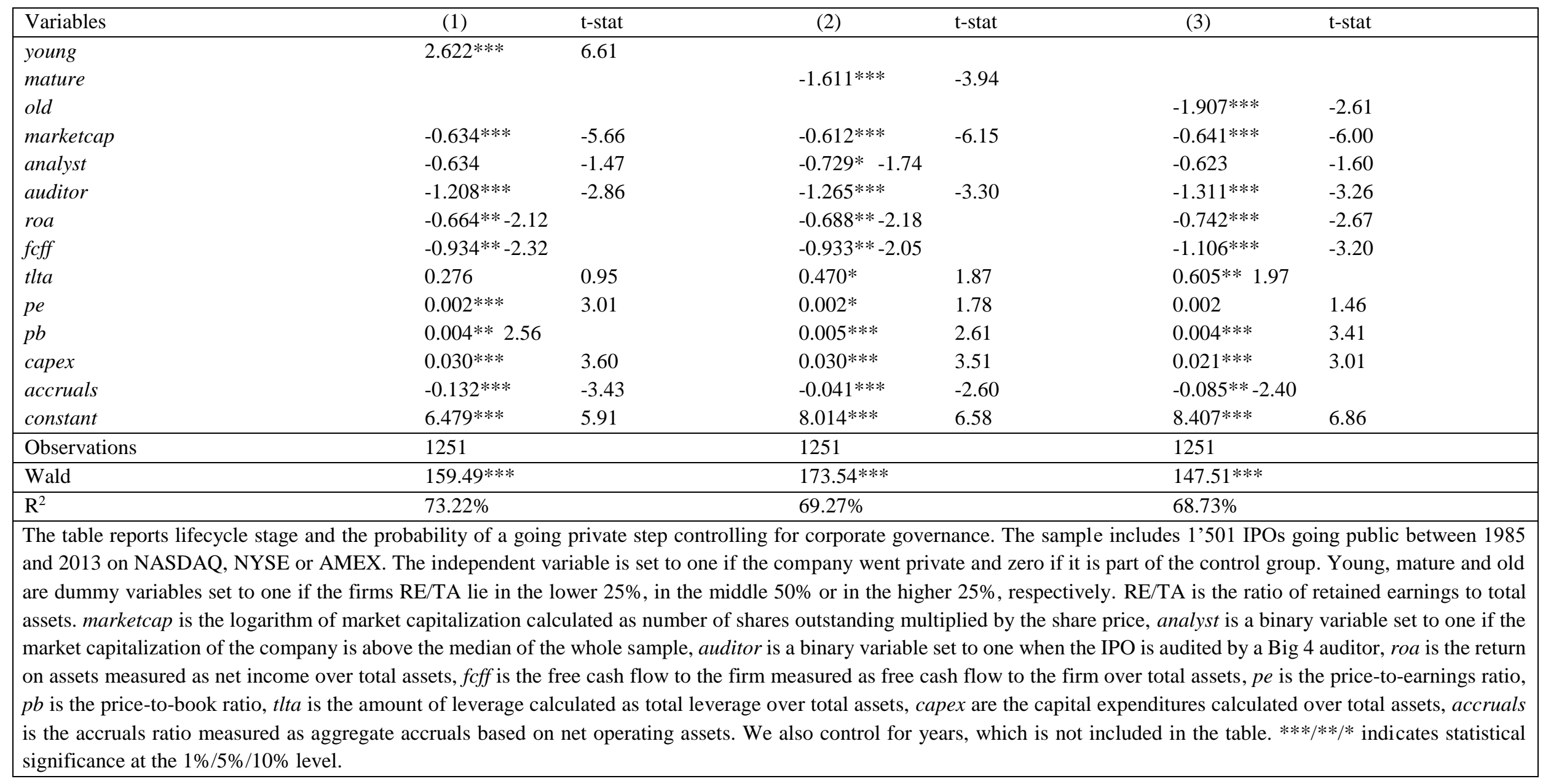


Also in this model, we approximate corporate lifecycle with retained earnings to total assets (RE/TA) following DeAngelo, DeAngelo, \& Stulz (2006) and Owen \& Yawson (2010). Our results further suggest that firms with higher amount of accumulated retained earnings, which we name mature (mature) and old (old) firms are those, which stay with higher probability public. All our results show significant evidence. In contrary to the regression model presented in table 5, the model in table 6 show no or just low significance for the influence of analyst coverage. Nonetheless, our finding still suggests that low analyst coverage is an indicator for a voluntary step into privacy. Our findings further imply that young firms with low amount of accruals are more likely to go private. This result is consistent with our analysis in table 4. Our results might be explained either through the unclear role of accruals (Louis \& Robinson, 2005) or through the point of time of the analysis. We conducted our analysis with data from the last public fiscal year in which firms might have already been focusing on a good level of their corporate governance due to the fact that they will soon change their ownership from public to private. All remaining variables tested in this model confirm the robustness of our previous results.

\section{Constraints}

Our study focus only on U.S. firms which went public during 1985 and 2013. Although it is a long examination period, it does not provide the overall picture. We further focus only on three major stock exchanges NYSE, AMEX and NASDAQ and neglect minor ones. Our empirical data is limited to the time when the examined firms have been public and had to disclose their financial statements. Our observation period starts already in 1985. Several companies decided for a step into privacy already some years after their IPO, which makes it difficult for us to find this historical data. This fact reduced our sample. In the previous decades, not only accounting standards, but also disclosure requirements changed. For our empirical study, we needed various fundamental and other quantitative data in order to describe firms and be able to test if they differ in their characteristics from firms that stay public. As only few data is available about firms, which were publicly listed a couple of years ago, data that we could use for characterization was also limited. In addition, we conduct our logit regressions only at a certain point in time and this is shortly before the announcement of the intention of firm to leave the public capital market. Accordingly, we collected data from the last public fiscal year. Even though our study is limited through various matters, the results of our logit regressions show remarkable high $\mathrm{R}^{2}$, which confirms that not only our approximation of lifecycle through accumulated retained earnings, but also the choice of further variables was not wrong.

\section{Summary}

This paper focuses on corporate lifecycle theories with the aim to further explain the going private phenomenon. Our main proxy for firm lifecycle is the relationship of retained earnings to total equity or assets, respectively. Our sample consists of 1'501 IPO firms, which went public on major U.S. exchanges between the years 1985 and 2013. Out of these IPO firms, 201 are voluntary going private firms and all others non-going privates firms, which represent the control group. We first examine whether corporate lifecycle has an impact on the likelihood of becoming a voluntary going private firm. Our findings suggest that approximations of retained earnings, once divided by total equity and once by total assets, both significantly influence the going private decision of firms. The lower is the amount of accumulated retained earnings the higher the probability of a voluntary delisting. Second, we analyze whether a particular lifecycle stage has the highest probability when a company decides to voluntary leave the public capital market. Our findings suggest that young firms identified as those with low amount of retained earnings to total assets are those with the highest likelihood to go private. Mature and old firms are significant more likely to stay public. Third, we control for the robustness of our results including corporate governance variable into our sample. We use three variables in order to measure for the corporate governance impact. CFO SOX certification (cfo sox) as well as the amount of accruals (accruals) are both significantly influencing the going private probability. We find no empirical evidence for the impact of auditor's opinion (auditor). Our findings are significant for both approximations with retained earnings to total equity as well as to total assets. Fourth, we examine the robustness of our results including the corporate governance variable CFO SOX certification ( $c$ fo sox) into our model and analyze its influence on lifecycle stages. We confirm our results from previous models, as on the one hand CFO SOX certification ( $c f o$ sox) highly significantly influences the going private decision and on the other hand increases the probability of young firms to decide to leave the public capital market voluntarily. Last, we examine influence of the second significant corporate governance variable, which is the amount of accruals (accruals). We find significant evidence for the negative influence of accruals on the going private decision. Our findings also confirm the results from previous models, as young firms are more likely to decide for a voluntary going private and mature and old firms mostly stay public. 
2523-6547 - Copyright: (C) 2017 The Authors. This is an open access article distributed under the terms of the Creative Commons Attribution License, which permits unrestricted use, distribution, and reproduction in any medium, provided the original author and source are credited. 


\section{References}

Adizes, I. (1979). Organizational passages_-Diagnosing and treating lifecycle problems of organizations.

Ambrose, B. W., \& Megginson, W. L. (1992). The Role of Asset Structure, Ownership Structure, and Takeover Defenses in Determining Acquisition Likelihood. The Journal of Financial and Quantitative Analysis, 27(4), 575-589. doi:10.2307/2331141

Bae, S. C., Chang, K., \& Kim, D. (2013). Determinants of target selection and acquirer returns: Evidence from cross-border acquisitions. International Review of Economics \& Finance, 27, 552-565. doi:10.1016/j.iref.2013.01.009

Bartley, J., \& Boardman, C. (1990). The relevance of inflation adjusted accounting data to the prediction of corporate takeovers. Journal of Business Finance \& .., 17(1), 53-72. doi:10.1111/j.14685957.1990.tb00549.x

Bartley, J. W., \& Boardman, C. M. (1986). Replacement-Cost-Adjusted Valuation Ratio as a Discriminator Among Takeover Target and Nontarget Firms, (Meade 1968), 41-55.

Belkaoui, A. (1978). Financial ratios as predictors of Canadian takeovers. Journal of Business Finance \& Accounting, 1(March 1977), 93-109.

Bell, R. G., Moore, C. B., \& Filatotchev, I. (2012). Strategic and institutional effects on foreign IPO performance: Examining the impact of country of origin, corporate governance, and host country effects. Journal of Business Venturing, 27, 197-216. doi:10.1016/j.jbusvent.2010.11.001

Bhabra, G. (2008). Potential targets: An analysis of stock price reactions to acquisition program announcements. Journal of Economics and Finance, 32(2), 158-175. doi:10.1007/s12197-007-9009-z

Bhabra, G. S. (2008). Potential targets: An analysis of stock price reactions to acquisition program announcements. Journal of Economics and Finance, 32(2), 158-175. doi:10.1007/s12197-007-9009-Z

Bharath, S. T., \& Dittmar, A. K. (2010). Why do firms use private equity to opt out of public markets? Review of Financial Studies, 23, 1771-1818. doi:10.1093/rfs/hhq016

Bi, X. G., \& Gregory, A. (2011). Stock Market Driven Acquisitions versus the Q Theory of Takeovers: The UK Evidence. Journal of Business Finance \& Accounting, 38(5-6), 628-656. doi:10.1111/j.14685957.2011.02234.x

Billett, M. T., Jiang, Z., \& Lie, E. (2010). The effect of change-in-control covenants on takeovers: Evidence from leveraged buyouts. Journal of Corporate Finance, 16(1), 1-15. doi:10.1016/j.jcorpfin.2009.09.005

Boot, A. W. A., Gopalan, R., \& Thakor, A. V. (2008). Market Liquidity, Investor Participation, and Managerial Autonomy: Why Do Firms Go Private? The Journal of Finance, 63(4), 2013-2059. doi:10.1111/j.15406261.2008.01380.x

Boubaker, S., Cellier, A., \& Rouatbi, W. (2014). The sources of shareholder wealth gains from going private transactions: The role of controlling shareholders. Journal of Banking \& Finance, 43, $226-246$. doi:10.1016/j.jbankfin.2014.03.025

Carow, K., Heron, R., \& Saxton, T. (2004). Do early birds get the returns? An empirical investigation of earlymover advantages in acquisitions. Strategic Management Journal, 25(6), 563-585. doi:10.1002/smj.404

Christensen, H. K., \& Montgomery, C. A. (1981). Corporate economic performance: Diversification strategy versus market structure. Strategic Management Journal, 2(4), 327-343. doi:10.1002/smj.4250020402

Company, P., Jensen, C., \& Meckling, H. (1976). THEORY OF THE FIRM : MANAGERIAL BEHAVIOR , AGENCY COSTS AND OWNERSHIP STRUCTURE I . Introduction and summary In this paper WC draw on recent progress in the theory of ( 1 ) property rights, firm . In addition to tying together elements of the theory of e, 3, 305-360.

Davis, G. F., \& Stout, S. K. (1992). Organization Theory and the Market for Corporate Control: A Dynamic Analysis of the Characteristics of Large Takeover Targets, 1980-1990. Administrative Science Quarterly, 37, 605-633. doi:10.2307/2393474

DeAngelo, H., DeAngelo, L., \& Rice, E. M. (1984). Going Private: Minority Freezeouts and Stockholder Wealth. The Journal of Law and Economics. doi:10.1086/467070 
DeAngelo, H., DeAngelo, L., \& Stulz, R. (2006). Dividend policy and the earned/contributed capital mix: a test of the life-cycle theory. Journal of Financial Economics, 81(2), 227-254. doi:10.1016/j.jfineco.2005.07.005

Denis, D. (1992). Corporate investment decisions and corporate control: Evidence from going-private transactions. Financial Management, 21(3), 80-94. Retrieved from http://www.jstor.org/stable/3666021

Dietrich, J. K., \& California, S. (1984). An Application of Logit Analysis to Prediction of Merger Targets, 10017, 393-402.

Evans, J., Poa, M., \& Rath, S. (2005). The Financial and Governance Characteristics of Australian Companies Going Private. International Journal of Business Studies, 13(1), 1-24.

Fama, E., \& Miller, M. (1972). The theory of finance. Retrieved from http://scholar.google.com/scholar?hl=en\&btnG=Search\&q=intitle:The+Theory+of+Finance\#0

Gaughan, P. (2011). Mergers, acquisitions, and corporate restructurings (5th. ed.).

Gaver, J. J., \& Gaver, K. M. (1993). Jennifer J. Gaver and Kenneth M. Gaver, 16, 125-160.

Gleason, K., Payne, B., \& Wiggenhorn, J. (2007). An empirical investigation of going private decisions of US firms. Journal of Economics and Finance, 31(2), 207-218. Retrieved from http://link.springer.com/article/10.1007/BF02751643

Grabowski, H. G., \& Mueller, D. C. (1975). Life-Cycle Effects on Corporate Returns on Retentions. The Review of Economics and Statistics, 57(4), 400-409. doi:10.2307/1935899

Greiner, L. (1997). Evolution and revolution as organizations grow. 1972. Harvard business review, 76(3), 55$60,62-6,68$.

Gutsche, R. (2013). Determinants of M\&A Activity and Control Concept-Firm Characteristics as Economic Indicators for Control in Business Combinations. Available at SSRN 2205914.

Halpern, P., Kieschnick, R., \& Rotenberg, W. (1999). On the heterogeneity of leveraged going private transactions. Review of Financial Studies, 12, 281-309. doi:10.1093/rfs/12.2.281

Harris, R., \& Stewart, J. (1982). Characteristics of acquired firms: fixed and random coefficients probit analyses. Southern Economic, 49(1), 164-184.

Hasbrouck, J. (1985). q and Other Measures, 9, 351-362.

Jensen, M. C. (1986). The Free Cash Flow Theory of Takeovers : A Financial Perspectfve on Met' gets and Acq uisitions and $\sim$ he Economy.

Jensen, M. C. (1987). The Free Cash Flow Theory of Takeovers : A Financial Perspective on Mergers and Acquisitions and the Economy. In The Merger Boom; Proceedings of a Conference Held in October 1987 (pp. 102-143). doi:http://dx.doi.org/10.2139/ssrn.350422

Jensen, M. C. (1988). Takeovers: Their causes and consequences. The Journal of Economic Perspectives, 2(1), 21-48.

Jensen, M. C., \& Ruback, R. S. (1983). The market for corporate control: The scientific evidence. Journal of Financial Economics, 11(1-4), 5-50. doi:10.1016/0304-405X(83)90004-1

Kieschnick, R. L. (1989). Management Buyouts of Public Coroprations: An Analysis of Prior Characteristics. In Y. Amihud, Leveraged management buyouts: causes and consequences (pp. 35-70). Homewood: Dow Jones-Irwin.

Kieschnick, R. L. (1998). Free cash flow and stockholder gains in going private transactions revisited. Journal of Business Finance \& Accounting, 25(March 1998), 187-202. Retrieved from http://onlinelibrary.wiley.com/doi/10.1111/1468-5957.00183/abstract

Krishnan, C. N. V., Ivanov, V. I., Masulis, R. W., \& Singh, A. K. (2011). Venture Capital Reputation, Post-IPO Performance, and Corporate Governance. Journal of Financial and Quantitative Analysis. doi:10.1017/S0022109011000251

Lehn, K., \& Poulsen, A. (1989). Free cash flow and stockholder gains in going private transactions. The Journal of Finance, 44(3), 771-787. doi:Article 
Loh, L. (1992). Financial characteristics of leveraged buyouts. Journal of Business Research, 24(3), 241-252. doi:10.1016/0148-2963(92)90021-3

Louis, H., \& Robinson, D. (2005). Do managers credibly use accruals to signal private information? Evidence from the pricing of discretionary accruals around stock splits. Journal of Accounting and Economics, 39, 361-380. doi:10.1016/j.jacceco.2004.07.004

Marris, R. (1964). The economic theory of managerial capitalism. The Economic Journal, 75, 403-404. doi: $10.2307 / 2229434$

Maupin, R. (1984). n Empirical Investigation of the Characteristics of Publicly-Quoted Corporations which Change to Closely-Held Ownership through Management Buyouts. Journal of Business Finance \& Accounting, 11(4), 435-450. doi:10.1111/j.1468-5957.1984.tb00762.x

Maupin, R. (1987). Financial and stock market variables as predictors of management buyouts. Strategic Management Journal, 8(4), 319-327. doi:10.1002/smj.4250080403

Mehran, H., \& Peristiani, S. (2010). Financial visibility and the decision to go private. Review of Financial Studies, 23(2), 519-547. doi:10.1093/rfs/hhp044

Miller, D., \& Friesen, P. (1984). A longitudinal study of the corporate life cycle. Management science, 30(10), 1161-1183. doi:10.1287/mnsc.30.10.1161

Owen, S., \& Yawson, A. (2010). Corporate life cycle and M\&A activity. Journal of banking \& finance, 34(2), $427-440$.

Palepu, K. (1982). A probabilistic model of corporate acquisitions. Retrieved from http://dspace.mit.edu/handle/1721.1/15688

Palepu, K. G. (1986). Predicting takeover targets: A methodological and empirical analysis. Journal of Accounting and Economics, 8(1), 3-35. doi:10.1016/0165-4101(86)90008-X

Powell, R. G. (2004). Takeover Prediction Models and Portfolio Strategies : A Multinomial Approach, 8(1), 3572.

Renneboog, L., Simons, T., \& Wright, M. (2007). Why do public firms go private in the UK? The impact of private equity investors, incentive realignment and undervaluation. Journal of Corporate Finance, 13(4), 591-628. doi:10.1016/j.jcorpfin.2007.04.005

Ritter, J. A. Y. R., \& Welch, I. V. O. (2002). A Review of IPO Activity , Pricing , and Allocations, LVII(4), 17951828.

Rumelt, R. P. (1982). Diversification strategy and profitability. Strategic Management Journal, 3(4), 359-369. doi: $10.1002 / \mathrm{smj} .4250030407$

Rydqvist, K., \& Högholm, K. (1995). Going public in the 1980s: Evidence from Sweden. European Financial Management, 1(3), 287-315. doi:10.1111/j.1468-036X.1995.tb00021.x

Shim, J., \& Okamuro, H. (2011). Does ownership matter in mergers? A comparative study of the causes and consequences of mergers by family and non-family firms. Journal of Banking \& Finance, 35(1), 193-203. doi:10.1016/j.jbankfin.2010.07.027

Shleifer, A., \& Vishny, R. W. (2003). Stock market driven acquisitions. Journal of Financial Economics, 70(3), 295-311. doi:10.1016/S0304-405X(03)00211-3

Singh, A. (1975). Take-overs, Economic Natural Selection, and the Theory of The Firm: Evidence from the Postwar. The Economic Journal, 85(339), 497-515.

Sorensen, D. E. (2000). Characteristics of merging firms. Journal of Economics and Business, 52(5), 423-433. doi:10.1016/S0148-6195(00)00028-X

Stevens, D. (1973). Financial characteristics of merged firms: A multivariate analysis. Journal of Financial and Quantitative Analysis, 8, 149-158.

Stimpert, J., \& Duhaime, I. (1997). Seeing the big picture: The influence of industry, diversification, and business strategy on performance. Academy of Management Journal, 40(3), 560-583.

Stubbart, C. I., \& Knight, M. B. (2006). The case of the disappearing firms: empirical evidence and implications. Journal of Organizational Behavior, 27(1), 79-100. doi:10.1002/job.361

2523-6547 - Copyright: (C) 2017 The Authors. This is an open access article distributed under the terms of the Creative Commons Attribution License, which permits unrestricted use, distribution, and reproduction in any medium, provided the original author and source are credited. 
Tobin, J. (1969). A general equilibrium approach to monetary theory. Journal of money, credit and banking, 1(1), 15-29. doi:10.2307/1991374

Trahan, E., \& Shawky, H. (1992). Financial characteristics of acquiring firms: an industry specific approach. Review of Financial Economics. Retrieved from http://scholar.google.com/scholar?hl=en\&btnG=Search\&q=intitle:Financial+characteristics+of+acquirin g+firms+An+industry+specific+approach\#0

Tsagkanos, A. (2008). Identification of Greek takeover targets and coherent policy implications. Review of Development Economics, 12(1), 180-192.

Weir, C., Laing, D., \& Wright, M. (n.d.). Incentive effects, monitoring mechanisms and the market for corporate control : an analysis of the factors affecting public to private transactions in the UK, $1-51$.

Wi Saeng Kim, \& Lyn, E. O. (1991). Going Private: Corporate Restructuring Under Information Asymmetry and Agency Problems. Journal of Business Finance \& Accounting, 18(5), 637-648. 
2523-6547 - Copyright: (C) 2017 The Authors. This is an open access article distributed under the terms of the Creative Commons Attribution License, which permits unrestricted use, distribution, and reproduction in any medium, provided the original author and source are credited. 